\title{
Variation in grain productivity and quality of modern winter wheat varieties in northern Ukrainian Steppe
}

\author{
M. Nazarenko*, S. Mykolenko, P. Okhmat \\ Dnipro State Agrarian and Economic University, 25 S. Efremova St, (Dnipro), \\ Dnipro region, Dnipro, 49600, Ukraine
}

*Corresponding author E-mail: nik nazarenko@ukr.net

Received: 09.08.2020. Accepted: 09.09.2020

\begin{abstract}
We have been studying the grain productivity and quality of 22 new winter wheat varieties during three years under North Ukrainian Steppe conditions. These 22 winter wheat varieties and control (national standard by grain productivity variety Podolyanka) were investigated regarding their interactions with environmental conditions by agronomic-value traits like as general grain productivity, components of one, protein and gluten content, developing relations between once (correlation relations), which determining wheat quality and yield in a complex. Two high-adaptive varieties Divo and Matrix, which provides us higher than standard grain yield in complex with higher or proper protein and gluten content were developed. Two factors permanently influenced on grain productivity (conditions of the year and genotype), while only one (genotype) determined the protein content of grains. We used the weight of thousand grains as an integrative parameter of the yield structure for all productive varieties, with no regards to yield formation.
\end{abstract}

Keywords: Winter wheat; Variety; Grain productivity; Grain protein

\section{Introduction}

One of the main tasks of bread wheat improvement at new century is using of local and international sources in breeding programs. Regarding the annual production of about 764.5 million tons (in 2019, USDA, 2020), bread wheat (Triticum aestivum L.) occupied the first place as a major cereal crop in the worlds trade. Wheat production and utilization accounts for $28 \%$ of the global cereal crops. Consequently, wheat supplies approximately one-fifth of human calories in a variety of forms. Wheat will remain a crucial component of human nutrition, and increasing its production is therefore an important requirement for food security. Wheat consumption has been steadily increasing due to population expansion and urbanization (Hongjie et al., 2019; Li et al., 2019).

Winter wheat is an important crop, suited to the typical weather conditions in the current climate. In a changing climate the increased frequency and severity of adverse weather events, which are often localized, are considered a major threat to wheat production (Harkness et al., 2020).

The improvement of grain productivity and its components of winter wheat through exploiting of trivial or novel methods of plant transformation lead to creation of new varieties with improved traits. The use of new breeding methods has become an important technique to optimize plant structure for bioproductivity (Naveed et al., 2015; Klčová et al., 2019).

One strategy to meet this challenge is to raise grain productivity by optimizing plant structure. As a sample of this investigation, the reduced height semi-dwarfing genes is one of the method to reduce stature of wheat (Triticum aestivum L.), and improve grain yield in terms of modern intensive phenotype (Gasperini et al., 2012).

Winter wheat is not only a world's leading cereal crop but also the most important food crop in Ukraine, which occupied leading position in the national agriculture (Nazarenko et al., 2019b). As for the quality traits winter wheat is the main stable crop for our country and provides more than $20 \%$ of calories and proteins. Focused on only yield traits we have to understand that any high yield has no sense without proper quality for food and fodder demands (Shewry et al., 2012). Wheat improvement, which bases on the principal of ecological stability of new forms and taking into account special interactions between environment and genotypes, special abilities for agroecological variability under wide ranges of conditions providing us new approaches for formation stable agroecological cereals systems without great losses at productivity (Bordes et al., 2011).

Key attention to pay for main agronomic-value traits such as grain productivity (and formation of this trait) and grain quality (in sense of grain protein content). These traits in interaction actually determine the overall genotypes of wheat by suitability for cultivation (Gepts \& Hancock, 2006). Winter wheat yield has the most important and complex character affected directly or indirectly by genome systems present in plant (Rangare et al., 2010) as well as interaction with environment (Tester \& Langridge, 2010; Serpolay et al., 2011). Thus, an ecological exam (part of evaluation process in breeding program for measurements of adaptation for new lines and varieties under difference regional conditions) of new wheat lines with high yield and quality genetic potential under difference condition, its components (Slafer \& Andrade, 1993) and interaction (Dawson et al., 2011) had become a permanent task in the plant farming and breeding programs (Reif et al., 2005; Tuberosa \& Salvi, 2006).

Grain storage proteins include about $60-80 \%$ of the total protein in wheat grains and metabolic proteins, remaining part consists of the albumins and globulins (15-20\%), which are produced by plants during the effective filling phase of plant development (Shewry et al., 2012, Bonnot et al., 2017, Khalili et al., 2018). Gluten proteins represent major protein fraction of the grain and are responsible for unique properties of the dough for bread-making industry (Bordes et al., 2008). Major determinants of wheat quality are storage grain proteins. Proteins from wheat flour combined with water formed gluten, which holds gas produced by yeast during baking (Anjum et al., 2007; Dai et al., 2015; Katyal et al., 2017). Strongly negative correlation between grain yield and grain protein 
is one of the most problem for winter wheat improvement on productivity an grain quality in complex (Slafer \&Andrade, 1993; Oury \& Godin, 2007; Tribo et al., 2003; Chope et al., 2014).

The objectives of our experiments are the description of the phenotypic and genotypic (part of dispersion, which determined only by genotype, not by climate or other factors) variability of the main agriculture-value traits of the new winter wheat lines according to their interactions with North Steppe environmental conditions. One of the main tasks was how reactions on specific conditions of our region of local, national and foreign breeding varieties are different from national official released varieties. Second our purpose to evaluate the variability of quantitative and qualitative traits of different winter wheat varieties grain and to compare newly bred winter wheat genotypes originated from local breeding programmers of Ukraine and other countries, possibilities of new genotypes in formation of ecological adaptation (Nazarenko, 2016).

\section{Materials and Methods}

Experiments were conducted at the experimental fields of Dnipropetrovsk State Agrarian and Economic University (48 $50^{\prime} \mathrm{N}$, $35^{\circ} 25^{\prime} \mathrm{E}$ ). The experimental field is lied on 59 meters above the sea level. Weather conditions for hydrothermal indicators during 2017-2019 varied, which made possible to obtain objective results, but in general, they were typical (air temperature during winter wheat growing season (September-July) is $8.5^{\circ} \mathrm{C}$, the average rainfall is $501 \mathrm{~mm}$ ) for the location of the research fields (air temperature during winter wheat growing season 2017 (September-July) was $9.2^{\circ} \mathrm{C}$, the average rainfall is about $433.8 \mathrm{~mm}$, some problem with insufficient of moisture in soil on May-June period; air temperature in season 2018 was $10.1^{\circ} \mathrm{C}$, the average rainfall is about $562.0 \mathrm{~mm}$, low content of moisture after winter period; air temperature in season 2019 was $9.6^{\circ} \mathrm{C}$, the average rainfall is about $522.8 \mathrm{~mm}$ ).

The experimental fields of Dnipro State Agrarian and Economic University use for many years (start from $60^{\text {th }}$ years of XX century) as an fields for intensive agricultural farming and researches. It is located about $28 \mathrm{~km}$ from Dnipro city (Olexandrivka village), which is enough to avoid industrial or town air pollution effects. The research fields occupy an area of 84 hectares. Soil type was normal chernozem; the locality belongs to a maize-wheat production type district of region. Special attention was paid to the differences on several agronomical-value traits (grain yield, protein and main protein components content in grains, assimilation of main macro- and microelements).

Winter wheat seeds were obtained from department of breeding and seedfarming of DSAEU (ecological exam). 22 varieties and 1 national standard on grain productivity Podolyanka. The recommended intensive agronomic practice was followed ( $\left.\mathrm{N}_{180}, \mathrm{P}_{60}, \mathrm{~K}_{40}\right)$. Evaluation of total grain yield of five lines per plot was calculated from 2017 to 2019 years. The control was national standard variety Podolyanka. The trial was set up at a randomized block design method with three replications and with a plot size of $5-10 \mathrm{~m}^{2}$ in 2-3 replications. The plot yield was converted to $t /$ ha. Data on yield structure components (plant height, number of productive culms, number of grain per spike, grain weight per spike, 1,000 grains weight) were taken from 50 randomly selected plants of each line representing properly morphological traits for this variety. Percent of grains in total productivity was calculated as weight of grains per plot on total weight of culms per plot. Agrochemical analysis of soils by content of nutrient elements was provided too ( $\mathrm{N}$ $\mathrm{NO}_{3}, \mathrm{mg} / \mathrm{kg} 24.7, \mathrm{P}_{2} \mathrm{O}_{5} 22.8, \mathrm{~K}_{2} \mathrm{O} 212$.

Wheat samples were held at room condition for 18-20 days before grinding. Each sample of $30 \mathrm{~g}$ was separately ground on a laboratory cyclone grinder (LMT-1, PLAUN LLC, Russia). Protein, gluten and water content of the samples were measured by Nearinfrared Reflectance Spectroscopy (Spectran-IT, Inari Technology CJSC, Russia). Triplicate data of each sample were averaged.

Mathematical processing of the results was performed by the method of analysis of variance, the variability of the mean difference was evaluated by Student's t-test, cluster and correlation analyses was conducted by module ANOVA. In all cases standard tools of the program Statistica 8.0 were used.

\section{Results and Discussion}

Investigated collection (23 varieties with standard) consists of three main groups. First group was modern national varieties (13 samples with Podolyanka), second one was varieties from Russian Federation (2 samples), third on consisted of 7 varieties from European Union (EU) countries and last enclosed only one variety from Turkey.

From 13 varieties of first group, some 4 anwless samples (prevalent 9 varieties with awn spikes, because one of the important foundations of national breeding was awn varieties more resist to pests damages), the most part of forms were medium by stem (6 samples), one high-stem, 4 short-stem, and only two semi-dwarf modern form. By maturing only four early forms (more suitable to our region) were developed. As for second group all from was short-stem, one medium and one early-medium and by phenotype this croup more correspondents to perspective Ukrainian variety model for winter wheat (Table 1).

At third group main parts of plant were awnless (only 1 exception), short-stem or semi-dwarf (1 exception), all forms late-maturing under conditions of region (only one medium-late). It was less variable group and unity by phenotype. One Turkish variety, Fotima, was anwless, semi-dwarf and late by maturing. This sample was correspond to normal for European varieties phenotype.

As a preliminary results of estimation, foreign varieties were differ by short-stem, primary awnless and late-maturing phenotype in spite of national and had in all cases desirable intensive phenotype (Nazarenko et al., 2019a). Ukrainian varieties can be subdivided on intensive (Laval, Dizhon, Valensiya, Hvala, Nasnaga, Askaniyska) or semi-intensive (Podolyanka and other samples) phenotype. First variant is desirable by the potential grain productivity and quality, but second one is considered as more reliable in yield realization under unfavorable year conditions. Podolyanka was realized as very stable variety at all for climate zone of Ukraine by yield traits.

Table 1. Origin and general characteristic of winter wheat varieties.

\begin{tabular}{lccccc}
\hline $\mathbf{N}$ & Variety & CoG & Awns & PH & Maturing \\
1 & Podolyanka, st & Ukr & awn & $\mathrm{m}$ & $\mathrm{m}$ \\
2 & Divo & $\mathrm{Ukr}$ & awn & $\mathrm{m}$ & $\mathrm{m}$ \\
3 & Metelitsya & $\mathrm{Ukr}$ & awn & $\mathrm{m}$ & $\mathrm{m}-\mathrm{I}$ \\
4 & Laval & $\mathrm{Ukr}$ & awnless & $\mathrm{s}-\mathrm{d}$ & $\mathrm{e}-\mathrm{m}$ \\
5 & Dizhon & $\mathrm{Ukr}$ & awn & $\mathrm{s}-\mathrm{d}$ & $\mathrm{e}-\mathrm{m}$ \\
6 & Valensiya & $\mathrm{Ukr}$ & awn & $\mathrm{s}$ & $\mathrm{m}-\mathrm{I}$ \\
7 & Raygorodka & $\mathrm{Ukr}$ & awnless & $\mathrm{m}$ & $\mathrm{m}$ \\
\hline
\end{tabular}


Variation in grain productivity and quality of modern

\begin{tabular}{lcllcc}
\hline & Pam'yati GIrka & Ukr & awn & $\mathrm{m}$ & $\mathrm{e}-\mathrm{m}$ \\
8 & Polisyanka & $\mathrm{Ukr}$ & awnless & $\mathrm{m}$ & $\mathrm{m}$ \\
9 & Zorepad BilotserkIvskiy & $\mathrm{Ukr}$ & awnless & $\mathrm{h}$ & $\mathrm{e}-\mathrm{m}$ \\
10 & Hvala & $\mathrm{Ukr}$ & awn & $\mathrm{s}$ & $\mathrm{m}$ \\
11 & Nasnaga & $\mathrm{Ukr}$ & awn & $\mathrm{s}$ & $\mathrm{m}$ \\
12 & Askaniyska & $\mathrm{Ukr}$ & awn & $\mathrm{s}$ & $\mathrm{I}$ \\
13 & Kazachka & Rus & awn & $\mathrm{s}$ & $\mathrm{m}$ \\
14 & Veha & Rus & awnless & $\mathrm{s}$ & $\mathrm{e}-\mathrm{m}$ \\
15 & Fotima & Tur & awnless & $\mathrm{s}$ & $\mathrm{I}$ \\
16 & Ilona & Svk & awn & $\mathrm{s}$ & $\mathrm{I}$ \\
17 & Figura & Pol & awnless & $\mathrm{m}$ & $\mathrm{I}$ \\
18 & Toras & Swe & awnless & $\mathrm{s}$ & $\mathrm{I}$ \\
19 & Manella & Nld & awnless & $\mathrm{s}-\mathrm{d}$ & $\mathrm{I}$ \\
20 & Anmitsa & Hrv & awnless & $\mathrm{s}$ & $\mathrm{I}$ \\
21 & Bodycek & Fra & awnless & $\mathrm{s}$ & $\mathrm{m}-\mathrm{I}$ \\
22 & Matrix & Deu & awnless & $\mathrm{s}-\mathrm{d}$ & $\mathrm{I}$ \\
23 & & & & & \\
\hline
\end{tabular}

CoG - country of origing; Ukr - Ukraine; Rus - Ukraine; Tur - Turkey; Svk - Slovakia; Pol - Poland; Swe - Sweden; Nld Niderlande; Hrv - Horvatia; Fra - France; Deu - Deutschland; PH - plant height; $\mathrm{h}$ - high-stem; $\mathrm{m}$ - medium; $\mathrm{s}$ - shortstem; sd - semidwarf; e-m - early-medium; m-I - medium-late; I - late

Analysis of grain productivity and its structure. Under field conditions, measurements were recorded grain yield (Table 2) main components of grain productivity such as number of productive culms, number of grains, grains weight of 1000 kernels, weight of grains from one main spike, weight of grains from $\mathrm{m}^{2}$. We registered that the winter wheat varieties are sensitive to growth in the different year conditions with statistical certainty (Table 3), but not within as wide a range as for factor of genotype and with some differences for classification groups (factor genotype regarding factor analysis $F=6.54 ; F_{\text {critical }}=1.78$; $p$-level 0.01 , factor year $F=3.99 ; F_{\text {critical }}=3.20$; p-level 0.05 ).

For the first parameter percent of grains in total productivity difference was developed between group of national varieties (average value 41.3 , main part of results at $40-43 \%$ level) and EU varieties (average value 48.0 , main part of results at $46-48 \%$ level).

As a result of grain yield analysis 6 varieties were developed as high-product (Divo, Metelitsya (first group), Veha (second), Figura, Manella, Matrix (third)). Some of the varieties have been developed under conditions of singular year without prevalence under standard at average: varieties Laval, Dizhon, Polisyanka, Zorepad Bilotserkivskiy, Bodycek under conditions of 2016-2017 vegetation year; Nasnaga under conditions of 2018-2019. Variety Pam'yati Girka was showed higher yield under conditions of two vegetation years without prevalence under standard regarding three years results.

Table 2. Yield and percent of grain.

\begin{tabular}{|c|c|c|c|c|c|c|}
\hline \multirow{2}{*}{$\mathbf{N}$} & \multirow{2}{*}{ Variety } & \multirow{2}{*}{ PGTP } & \multicolumn{4}{|c|}{ Yield, t/ha } \\
\hline & & & 2017 & 2018 & 2019 & average \\
\hline 1 & Podolyanka, st & 40.1 & 5.50 & 7.10 & 5.76 & 6.12 \\
\hline 2 & Divo & 41.3 & 7.06* & $8.11^{*}$ & $8.28 *$ & $7.82 *$ \\
\hline 3 & Metelitsya & 41.0 & 6.18 & $8.11^{*}$ & $7.69 *$ & $7.33^{*}$ \\
\hline 4 & Laval & 42.9 & $6.68 *$ & 5.86 & 5.34 & 5.96 \\
\hline 5 & Dizhon & 42.0 & $6.54 *$ & 5.93 & 5.14 & 5.87 \\
\hline 6 & Valensiya & 43.0 & 6.01 & 7.27 & 6.37 & 6.55 \\
\hline 7 & Raygorodka & 40.6 & 6.21 & 7.82 & 6.21 & 6.75 \\
\hline 8 & Pam'yati Girka & 43.0 & $6.54 *$ & 7.32 & $6.96 *$ & 6.94 \\
\hline 9 & Polisyanka & 42.6 & $6.43^{*}$ & 6.11 & 5.07 & 5.87 \\
\hline 10 & Zorepad Bilotserkivskiy & 34.2 & $6.40 *$ & 7.78 & 6.65 & 6.94 \\
\hline 11 & Hvala & 42.7 & 5.60 & 5.07 & 5.48 & 5.38 \\
\hline 12 & Nasnaga & 41.2 & 6.10 & 6.97 & $6.88^{*}$ & 6.65 \\
\hline 13 & Askaniyska & 42.7 & 5.14 & 6.21 & 5.97 & 5.77 \\
\hline 14 & Kazachka & 48.9 & 4.89 & 5.64 & 5.91 & 5.48 \\
\hline 15 & Veha & 47.1 & $6.90 *$ & 7.92 & $7.48^{*}$ & $7.43^{*}$ \\
\hline 16 & Fotima & 49.0 & 6.10 & 5.79 & 5.43 & 5.77 \\
\hline 17 & Ilona & 47.4 & 6.11 & 4.72 & 5.01 & 5.28 \\
\hline 18 & Figura & 46.6 & $6.79 *$ & 7.19 & $7.62 *$ & $7.20 *$ \\
\hline 19 & Toras & 47.8 & 3.13 & 4.89 & 4.00 & 4.01 \\
\hline 20 & Manella & 48.9 & 6.17 & 7.14 & $7.72 *$ & $7.01 *$ \\
\hline 21 & Anmitsa & 46.8 & 6.01 & 5.12 & 5.32 & 5.48 \\
\hline 22 & Bodycek & 47.6 & $7.12 *$ & 6.16 & 6.67 & 6.65 \\
\hline \multirow[t]{3}{*}{23} & Matrix & 51.2 & $6.80 *$ & 7.70 & $7.45^{*}$ & $7.32 *$ \\
\hline & Average & 44.3 & 6.10 & 6.61 & 6.28 & 6.33 \\
\hline & Std. deviation & 3.9 & 0.84 & 0.90 & 0.96 & 0.88 \\
\hline
\end{tabular}

PGTP - percent of grains in total productivity, * indicate significant differences from standard at $P<0.05$. 
Significant differences were observed between vegetative years in yield. In three evaluated traits, higher average value of yield were found in 2017-2018 and 2018-2019 compared to previous one, but for genotypes Podolyanka, Laval, Dizhon, Valensiya, Raygorodka, Polisyanka, Zorepad Bilotserkivskiy, Veha Fotima conditions of 2017-2018 were significantly more favorable, for Figura, Manella, Bodycek conditions of 2018-2019 vegetative year was better. As an interesting fact, in terms of these two years for varieties of third group 2018-2019 years conditions were more suitable or was no differences between years, for first group in 20172018 for higher for most part of cases, for other yield was on the same level. In 2016-2017, the grain yield was significantly lower for the most part of genotypes, excepted standard Podolyanka (on the level of 2018-2019), varieties Laval, Dizhon, Anmitsa, Bodycek which showed highest level of yield.

As result of total yield analysis only one variety Divo demonstrated predominance under standard all three years and can be developed as high-productive stable form. Varieties Metelitsya, Veha, Figura, Matrix showed prevalence during two growing periods and enough by stability of this parameters for proper exploitation. Variety Manella and Pam'yati Girka need in further researches by their grain productivity potential. Genotypes which provided higher yield and more severity conditions of 2016-2017 vegetation period may be considered as the sources of tolerance to more severe weather conditions.

Yield is affected by environmental factors, e.g. weather conditions and soil type and quality, what was also expressed in significant action years conditions. Similarly, in winter wheat (Žofajová et al., 2017) found that genotype, year and location significantly influenced on yield and yield components.

Higher precipitations in the period of intensive growth in the vegetation's of 2017-2018 and 2018-2020 induced higher grain productivities compared to the previous vegetation 2016-2017 year which provided information about more tolerance for insufficient in moisture forms.

Significant differences were found among varieties in all evaluated traits. By number of productive culms varieties Divo, Metelitsya, Nasnaga were developed with statistically significance, by number of grains from main spike Metelitsya, Veha, Manella, Matryx, by weight of thousand grains Divo, Metelitsya, Veha, Figura, Manella, Matrix (just the same as for yield), by grain weight from main spike Veha, Figura, Manella, Matrix, by grain weight from $\mathrm{m}^{2}$ Divo, Metelitsya, Valensiya, Pam'yati Girka, Zorepad Bilotserkivskiy, Veha, Figura, Bodycek, Matrix.

According to dates there was one key moment in a yield formation. Varieties Divo, Metelitsya in grain productivity depended on possibility to form a yield due to the number of productive culms, other varieties depended on grain weight from main spike. They formed less culms but obtained prevalence by yield with number and sizes of grains (Veha, Figura, Manella, Matrix). But at both cases high-productive genotype has been parameter of thousand grain weight identified (Bhutta et al., 2005).

Early maturing varieties are considered to have an advantage in yield in the Steppe region of Ukraine. This point of view has been partially confirmed, since this type of development precisely avoids the spring-summer drought in Dnipro region (May-June), which falls on the critical phases of development and occurs virtually every third year. As we can see, just a few early-mid-maturing varieties mainly in the experiment formed a yield above the standard. However, most such varieties were not so successful in subsequent years. Climate change has already led to a mitigation of this effect for our region and an increase in rainfall during the growing season, although their distribution can still not be considered rational and the region belongs to the risky farming zone for cereal crops (Mba et al., 2012).

Table 3. Components of winter wheat grain productive structure.

\begin{tabular}{ccccccc}
\hline $\mathbf{N}$ & Parameter & NPC & GN & TGW & GW & GWM \\
1 & Podolyanka, st & 540 & 23 & 41.4 & 1.02 & 626 \\
2 & Divo & $591^{*}$ & 27 & $45.3^{*}$ & 1.06 & $777^{*}$ \\
3 & Metelitsya & $599^{*}$ & $28^{*}$ & $46.1^{*}$ & 1.04 & $734^{*}$ \\
4 & Laval & 533 & 19 & 41.8 & 0.91 & 614 \\
5 & Dizhon & 513 & 24 & 42.2 & 1.03 & 611 \\
6 & Valensiya & 571 & 22 & 40.6 & 1.00 & $701^{*}$ \\
7 & Raygorodka & 503 & 27 & 42.2 & 1.12 & 653 \\
8 & Pam'yati Girka & 543 & 26 & 41.6 & 1.09 & $712^{*}$ \\
9 & Polisyanka & 511 & 22 & 40.8 & 1.00 & 588 \\
10 & Zorepad & 556 & 23 & 43.4 & 1.11 & $711^{*}$ \\
11 & Bilotserkivskiy & & & & & \\
12 & Hvala & 500 & 18 & 40.2 & 0.96 & 578 \\
13 & Nasnaga & $587 *$ & 22 & 41.6 & 1.12 & 667 \\
14 & Askaniyska & 484 & 20 & 40.4 & 1.00 & 594 \\
15 & Kazachka & 500 & 22 & 39.0 & 0.92 & 567 \\
16 & Veha & 578 & $28^{*}$ & $44.7 *$ & $1.18^{*}$ & $744^{*}$ \\
17 & Fotima & 498 & 22 & 40.0 & 1.01 & 601 \\
18 & Ilona & 474 & 22 & 39.1 & 0.87 & 561 \\
19 & Figura & 511 & 31 & $47.9 *$ & $1.29 *$ & $742^{*}$ \\
20 & Toras & 467 & 23 & 41.2 & 0.97 & 511 \\
21 & Manella & 532 & $33^{*}$ & $48.2^{*}$ & $1.21^{*}$ & 657 \\
22 & Anmitsa & 511 & 23 & 41.2 & 1.01 & 601 \\
23 & Bodycek & 532 & 24 & 43.2 & 1.09 & $689^{*}$ \\
& Matrix & 548 & $32^{*}$ & $48.4^{*}$ & $1.23^{*}$ & $722^{*}$ \\
& Average & 530 & 24 & 42.6 & 1.05 & 650 \\
\hline
\end{tabular}

NPC - number of productive culms[piece]; GN - grain number per ear [piece]; TGW - thousand grain weight [g]; GW grain weight per ear $[\mathrm{g}]$; GWM - grain weight per $\mathrm{m}^{2}[\mathrm{~g}]$

* indicate significant differences from standard at $P<0.05$ 
However, in the new conditions, varieties of the European ecotype (more similar to our Polesye type) are already competing in environmental adaptability and stability at the level of the best national varieties, exceeding the standard in productivity.

National varieties in their grain productivity depend on the ability to form a crop due to the high number of productive stems, while others (EU) form a crop due to the mass of grain from the main head. They are characterized by fewer number of productive stems, but get an advantage due to the high number of grains per head. However, in both cases, highly productive genotypes are characterized by the presence of a high mass of a thousand grains. That is, this parameter serves as reliable and integrative indicators of high productivity regardless of the mechanism of its formation. This statement is consistent with preliminary studies for cereal crops (Nazarenko et al., 2019a).

We calculated the data on the quality of grain of winter wheat varieties (moisture content, protein content, gluten content). Threeyears data were summarized and the mean values were presented. Grain quality depends on genotype, under unfavorable years varieties maintained their grain quality due to yield loss. This fact is according to previous investigations (Tsenov et a/ 2015) (factor genotype $F=5.17 ; F_{\text {critical }}=1.96$; p-level 0.01 ; factor year $F=1.97 ; F_{\text {critical }}=2.12 ; p$-level 0.18$)$. As we can see, in general, only part of the varieties corresponds to the category of strong wheat (protein content on the level of 14\%). Moreover, only two varieties from the European group correspond to this parameter (Anmitsa, Matrix), whereas 9 correspondent varieties are of Ukrainian selection. The one variety of Turkish selection does not meet this standard. One of the two varieties of Russian breeding corresponds to this parameter, and the other (highly productive) does not.

However, it should be noted that only a few varieties exceeded the standard (which generally shows fairly average parameters of quality, although it applies to strong wheat). We can also note that such varieties are only among the group of domestic selection genotypes, which shows that the problem of grain quality in terms of this indicator is both non-critical for us and solved quite promisingly. While among European varieties, most of the genotypes do not meet our standards for this parameter. Of particular note is Divo variety, which combines high quality and yield. Another highly productive genotypes that deserve attention are Matrix variety, which has a sufficient protein content at high yields. The remaining such genotypes (Metelitsya, Veha, Figura, Manella, Matrix) have unsatisfactory parameters (Table 4).

As for the gluten content, in general, its dynamics is similar to the protein content.

Table 4. Winter wheat grain quality parameters.

\begin{tabular}{|c|c|c|c|c|}
\hline $\mathbf{N}$ & Variety & M & PC & GC \\
\hline 1 & Podolyanka, st & 14.72 & $13.99 \pm 0.31$ & $25,59 \pm 1.10$ \\
\hline 2 & Divo & 14.34 & $14.48 \pm 0.22 *$ & $27.43 \pm 0.92$ \\
\hline 3 & Metelitsya & 14.78 & $12.30 \pm 0.18$ & $21.03 \pm 0.73$ \\
\hline 4 & Laval & 14.12 & $13.47 \pm 0.23$ & $24.79 \pm 0.93$ \\
\hline 5 & Dizhon & 14.44 & $12.34 \pm 0.34$ & $21.84 \pm 1.12$ \\
\hline 6 & Valensiya & 14.50 & $15.01 \pm 0.20 *$ & $28.91 \pm 0.84 *$ \\
\hline 7 & Raygorodka & 14.79 & $14.33 \pm 0.19$ & $26.72 \pm 0.93$ \\
\hline 8 & Pam'yati GIrka & 14.55 & $14.00 \pm 0.26$ & $26.26 \pm 0.99$ \\
\hline 9 & Polisyanka & 14.59 & $12.99 \pm 0.32$ & $24.24 \pm 1.21$ \\
\hline 10 & Zorepad Bilotserkivskiy & 15.20 & $15.43 \pm 0.17 *$ & $30.39 \pm 0.79 *$ \\
\hline 11 & Hvala & 14.40 & $13.11 \pm 0.41$ & $25.12 \pm 1.15$ \\
\hline 12 & Nasnaga & 14.44 & $13.99 \pm 0.23$ & $25.88 \pm 0.91$ \\
\hline 13 & Askaniyska & 14.85 & $14.84 \pm 0.18^{*}$ & $28.52 \pm 0.85^{*}$ \\
\hline 14 & Kazachka & 14.39 & $14.00 \pm 0.23$ & $26.03 \pm 0.99$ \\
\hline 15 & Veha & 14.14 & $13.06 \pm 0.31$ & $23.62 \pm 1.22$ \\
\hline 16 & Fotima & 14.26 & $12.35 \pm 0.26$ & $22.41 \pm 0.97$ \\
\hline 17 & Ilona & 14.00 & $10.67 \pm 0.45$ & $18.26 \pm 1.31$ \\
\hline 18 & Figura & 14.66 & $11.43 \pm 0.24$ & $19.85 \pm 0.93$ \\
\hline 19 & Toras & 14.24 & $12.49 \pm 0.29$ & $23.09 \pm 0.95$ \\
\hline 20 & Manella & 14.84 & $11.55 \pm 0.37$ & $20.12 \pm 1.14$ \\
\hline 21 & Anmitsa & 15.72 & $13.99 \pm 0.21$ & $26.43 \pm 0.86$ \\
\hline 22 & Bodycek & 12.53 & $11.9 \pm 0.32$ & $21.28 \pm 1.17$ \\
\hline \multirow[t]{3}{*}{23} & Matrix & 15.17 & $13.83 \pm 0.19$ & $24.90 \pm 0.77$ \\
\hline & Average & 14.68 & 13.28 & $24.47 \pm$ \\
\hline & Std. deviation & 0.63 & 0.45 & 2.11 \\
\hline
\end{tabular}

Considering the results, interesting is the relationship between the studied characteristics. In general, the obtained correlation matrix confirms the previous conclusions. Strong positive relationships between grain number per ear, thousand grain weight, grain weight per ear, grain weight per $\mathrm{m}^{2}$, yield were developed. Number of productive culms have such relationships with grain weight per ear, grain weight per $\mathrm{m}^{2}$ and yield, however not with thousand grain weight, which is somewhat contrary to previous conclusion about closely relationship between grain productivity and thousand grain weight, but it is rather related to interceptions of such a relation in less productive varieties. There is no correlation between quantity and quality traits in spite of previous investigations (strong negative correlation) (Oury \& Godin, 2007, Nazarenko et al., 2019a).

Thus, like as previous (Bordes et al., 2011, Nazarenko, 2016, Nazarenko et al., 2019b) grain quality are more depended on genotype of variety. In spite of quality, grain productivity is depended on both genotype and growth conditions, like as at previous investigations (Serpolay et al., 2011; Milev et al., 2014). In complex (by quantity and quality traits) we can recommend varieties 
Divo and Matrix as full suitable by all parameters for Northern Steppe subzone (for our Dnipro region), variety Pam'yati GIrka, Anmitsa need father investigations by agronomic-value traits complex.

To sum it up, investigations in terms of ecological exam shows us, that the level of regional variability under specific climatic conditions is enough for significance discrepancies in genotype-environment reaction (Žofajová et al., 2017) and, thus, for unsuccessful even for varieties obtaining in results of special breeding program for conditions of geographic zone (Steppe of Ukraine) and according to general variety model for this zone and successful for other genotypes (Table 5).

The wide phenotypic variability for the main of the agricultural-value traits investigated is shown of the large diversity amohg the varieties and genotype-environment interactions, mutual influences of climatic conditions and genotype peculiarities (Nazarenko, 2016; Nazarenko et al., 2019b).

Table 5. Correlations of between parameters of grain productive structure and quality.

\begin{tabular}{cccccccccc}
\hline Trait & NPC & $\mathbf{G N}$ & TGW & $\mathbf{G W}$ & $\mathbf{G W M}$ & PGTP & Yield & PC & GC \\
NPC & -- & 0,33 & 0,47 & 0,39 & $\mathbf{0 , 8 1}$ & $-0,27$ & $\mathbf{0 , 7 9}$ & 0,33 & 0,25 \\
GN & 0,33 & -- & $\mathbf{0 , 8 9}$ & $\mathbf{0 , 8 2}$ & $\mathbf{0 , 6 3}$ & $-0,12$ & $\mathbf{0 , 6 7}$ & $-0,26$ & $-0,34$ \\
TGW & 0,47 & $\mathbf{0 , 8 9}$ & -- & $\mathbf{0 , 8 3}$ & $\mathbf{0 , 7 1}$ & $-0,14$ & $\mathbf{0 , 7 3}$ & $-0,20$ & $-0,27$ \\
GW & 0,39 & $\mathbf{0 , 8 2}$ & $\mathbf{0 , 8 3}$ & -- & $\mathbf{0 , 7 0}$ & $-0,15$ & $\mathbf{0 , 7 2}$ & $-0,04$ & $-0,10$ \\
GWM & $\mathbf{0 , 8 1}$ & $\mathbf{0 , 6 3}$ & $\mathbf{0 , 7 1}$ & $\mathbf{0 , 7 0}$ & -- & $-0,32$ & $\mathbf{0 , 9 6}$ & 0,19 & 0,13 \\
PGTP & $-0,27$ & $-0,12$ & $-0,14$ & $-0,15$ & $-0,32$ & -- & $-0,32$ & $-0,28$ & $-0,27$ \\
Yield & $\mathbf{0 , 7 9}$ & $\mathbf{0 , 6 7}$ & $\mathbf{0 , 7 3}$ & $\mathbf{0 , 7 2}$ & $\mathbf{0 , 9 6}$ & $-0,32$ & -- & 0,17 & 0,09 \\
PC & 0,33 & $-0,26$ & $-0,20$ & $-0,04$ & 0,19 & $-0,28$ & 0,17 & -- & $\mathbf{0 , 9 9}$ \\
GC & 0,25 & $-0,34$ & $-0,27$ & $-0,10$ & 0,13 & $-0,27$ & 0,09 & $\mathbf{0 , 9 9}$ & -- \\
\hline
\end{tabular}

NPC - number of productive culms, GN - grain number per ear, TGW - thousand grain weight, g, GW - grain weight per ear, g, GWM - grain weight per $\mathrm{m}^{2}$, g, PGTP - percent of grains in total productivity, PC - protein content, \%, GS - gluten content, \%

\section{Conclusion}

Thus, both of the discovered mechanisms for the formation of higher yields generally lead to the same results. We should note that a more rational plant architecture in European varieties does not lead to a complete predominance in terms of the manifestation of economically valuable characters over varieties of domestic selection, although it allows them to equally compete even based on the fact that they were designed for less severe climatic zones. In contrast to the problems of high productivity, the problem of grain quality still requires great efforts for researchers, and we further plan to examine this parameter in more detail in terms of individual protein components and to identify some valuable sources of this character. Attention should also be paid not only to overall productivity and its components, but also separately to indicators of resistance to abiotic stresses typical of our region (winter and drought tolerance). However, in general, the most promising forms have already been identified that can be used both directly in production to increase yield and grain quality, and as a source of these characteristics in programs for obtaining new varieties. Forms combining superiority over the standard in terms of yield and quality or superiority in one character with the value of another at the standard level are still rare. Although the national standard cannot be attributed to fairly new forms.

\section{References}

Anjum F.M., Khan M.R., Din, A., Saeed, M., Pasha, I. \& Arshad, M.U. (2007). Wheat gluten: high molecular weight glutenin subunits - structure, genetics, and relation to dough elasticity, Journal of Food Science, 72 (3), 56-63.

Bhutta W.M., Akhtar J., Anwar-ul-haq M. \& Ibrahim M. (2005). Cause and effect relations of yield components in spring wheat (Triticum aestivum L.) under normal conditions, Caderno de Pesquisa Serie Biologia, Santa Cruz do Sul, 17(1), 7-12.

Bonnot T., Bance E., Alvarez D., Davanture M., Boudet J., Pailloux M., Zivy M. Ravel C. \& Martre P. (2017). Grain subproteome responses to nitrogen and sulfur supply in diploid wheat Triticum monococcum ssp. Monococcum, The Plant Journal, 91(5), 894910.

Bordes J., Ravel C., Le Gouis J., Lapierre A., Charmet G. \& Balfourier F. (2011). Use of a global wheat core collection for association analysis of flour and dough quality traits. Journal of Cereal Science, 54, 137-134.

Bordes J., Branlard G., Oury F.X., Charmet G. \& Balfourier G. F. (2008). Agronomic characteristics, grain quality and flour rheology of 372 bread wheats in a worldwide core collection, Journal of Cereal Science, 48(3), 569-579.

Chope G.A., Wan Y., Penson S.P., Bhandari D.G., Powers S.J., Shewry P.R. \& Hawkesford M.J. (2014). Effects of genotype, season, and nitrogen nutrition on gene expression and protein accumulation in wheat grain, Journal of Agricultural Food Chemistry, 62, 4399-4407.

Dai Z., Plessis A. \& Vincent J. (2015). Transcriptional and metabolic alternations rebalance wheat grain storage protein accumulation under variable nitrogen and sulfur supply, Plant Journal, 83, 326-343.

Dawson J. C., Rivire P. \& Berthellot J. F. (2011). Collaborative Plant Breeding for Organic Agricultural Systems in Developed Countries, Sustainability, 3, 1206-1223.

Gasperini D., Greenland A., Hedden P., Dreos R., Harwood W. \& Griffiths S. (2012). Genetic and physiological analysis of Rht8 in bread wheat: an alternative source of semi-dwarfism with a reduced sensitivity to brassinosteroids, Journal of Experimental Botany, $63,4419-4436$.

Gepts P. \& Hancock J. (2006). The future of plant breeding, Crop Science, 46, 1630-1634. 
Harkness C., Semenov M. A. \& Areal F. (2020). Adverse weather conditions for UK wheat production under climate change, Agricultural and Forest Meteorology, 1078622, 282-283.

HONGJIE L., TIMOTHY D.M., INTOSHC R.A. \& YANG Z. (2019). Breeding new cultivars for sustainable wheat production, The Crop Journal, 7(6), 715-717.

Katyal M., Virdi S.V., Kaur A., Singh N., Kaur S., Ahlawat A.K. \& Singh A.M. (2016). Diversity in quality traits amongst Indian wheat varieties I: Flour and protein characteristics, Food Chemistry, 194, 337-344.

Khalili M., Naghavi M. \& Yousefzadeh S. (2018). Protein pattern analysis in tolerant and susceptible wheat cultivars under salinity stress conditions, Acta agriculturae Slovenica, 111(3), 545-558.

Klčová L., Ondreičková K., Mihálik D. \& Gubišová M. (2019). The choice of suitable conditions for wheat genetic transformation. Agriculture (Polnohospodárstvo), 65 (1), 30-36.

Li H.J., Timothy D. M., Mc Intoshc R.A. \& Zhou Y. (2019). Wheat breeding in northern China: achievements and technical advances, The Crop Journal, 7(6), 718-729.

Mba C., Guimaraes E.P. \& Ghosh K. (2012). Re-orienting crop improvement for the changing climatic conditions of the 21st century, Agriculture \& Food Security, 7, 1-17.

Milev G., Nankov N. Iliev I., Ivanova A. \& Nankova M. (2014). Growing Wheat (Trititcum aestivum L.) by the Methods of Organic Agriculture Under the Conditions of Dobrudzha Region, Bulgaria, Turkish journal of agricultural and natural sciences, 1, 849-857.

Naveed A., Nazir A., Abdu H., Raza S. \& Muhammad A. (2015). Mutation breeding: a tool to improve wheat yield and yield components, Life Science, 9(1), 3274-3279.

Nazarenko M. (2016). Identification and characterization of mutants induced by gamma radiation in winter wheat (Triticum aestivum L.), Scientific Papers series A. Agronomy, 59, 350-353.

Nazarenko M., Mykolenko S., \& Chernysky V. (2019). Modern ukrainian winter wheat varieties grain productivity and quality at ecological exam, Agriculture and Forestry, 65(1), 127-136.

Nazarenko M., Solohub, I. \& Izhboldin, O. (2019). Winter wheat variability according to local conditions, Acta agriculturae Slovenica, $114(1), 113-129$.

Rangare N.R., Krupakar A., Kumar,A. \& Singh S. (2010). Character association and component analysis in wheat (Triticum aestivum L.), Electronic Journal of Plant Breeding, 1, 231-238.

Reif J.C., Zhang P., Dreisigacker S. \& Warburton M.L. (2005). Wheat genetic diversity trends during domestication and breeding, Theoretical and Applied Genetics, 110, 859-864.

Serpolay E., Dawson J.C., Chable V., Van Bueren L., Osman A., Pino S., Silveri D. \& Goldringer, I. (2011). Phenotypic responses of wheat landraces, varietal associations and modern varieties when assessed in contrasting organic farming conditions in Western Europe, Organic Agriculture, 3, 12-18.

Shewry P.R., Mitchell R.A.C. \& Tosi P. (2012). An integrated study of grain development of wheat (cv. Hereward), Journal of Cereal Science, 56, 21-30.

Slafer G.A. \& Andrade F.H. (1993). Physiological attributes related to the generation of grain yield in bread wheat cultivars released at different eras, Field Crops Research, 31, 351--367.

Tester M. \& Langridge P. (2010). Breeding technologies to increase crop production in a changing world, Science, 327, 818-822.

Tsenov N., Atanasova D., Stoeva I. \& Tsenova E. (2015). Effects of drought on grain productivity and quality in winter bread wheat, Bulgarian Journal Agricultural Sciences, 21, 592-598.

Tribo E., Martre P. \& Tribo-Blondel A.M. (2003). Environmentally induced changes in protein composition in developing grains of wheat are related to changes in total protein content, Journal of Experimental Botany, 54, 1731-1742.

Tuberosa R. \& Salvi S. (2006). Genomics-based approaches to improve drought tolerance of crops, Trends in Plant Science, 11, 405412.

Oury F. X. \& Godin C. (2007). Yield and grain protein concentration in bread wheat: how to use the negative relationship between the two characters to identify favourable genotypes? Euphytica, 157(1-2), 45-57.

Žofajová A., Havrlentová M., Ondrejovič M., Juraška M., Michalíková B. \& Deáková L. 2017. Variability of quantitative and qualitative traits of coloured winter wheat. Agriculture (Polnohospodárstvo), 63(3), 102-111.

United states department of agriculture. 2020. World Agricultural Production.

\section{Citation:}

Nazarenko, M., Mykolenko, S., Okhmat, P. (2020). Variation in grain productivity and quality of modern winter wheat varieties in northern Ukrainian Steppe. Ukrainian Journal of Ecology, 10(4), 102-108. 